\title{
IS THERE A NEED TO REGULATE MEDIATION? THE ENGLISH AND WELSH CASE STUDY
}

The use of mediation in England and Wales is nowadays an accepted and common practice within the alternative dispute resolution industry. Credited professionals have been performing the duties of a mediator in different fields of legal disputes; however, despite the positive perception of mediation, this area remains unregulated. So far, the rules applying to mediation in England and Wales originate from case law and contract between the parties. Such a scenario is not shared by other countries in which mediation has been regulated through an Act covering either private or judicial mediation. This article examines the current mediation scenario in England and Wales to assess whether there is a need to give it a statutory character in a similar manner to other jurisdictions.

\section{Introduction}

The use of mediation to solve disputes is not a new phenomenon; ${ }^{1}$ however, its employment as an alternative dispute resolution (ADR) method gained popularity rather recently. ${ }^{2} \mathrm{H}$ Genn, $\mathrm{S}$ Riahi and K Pleming stated that after the 1990s, England and Wales had a breakthrough of policies towards the acceptance and implementation of mediation, especially in the civil and family justice system. ${ }^{3}$ Even today there is no Mediation Act controlling the practice and procedure of mediation in England and Wales, which might sound strange because the statistics related to the practice of mediation in England and Wales show a significant number of mediation cases. For instance, in 2014, the Centre for Effective Dispute Resolution (CEDR) reported 9,500 commercial mediation cases per annum in England and Wales. ${ }^{4}$ Moreover, the information obtained by the Ministry of Justice statistics bulletin shows that from January 2014 to September 2014, 5,430 family mediation cases commenced in England and Wales. ${ }^{5}$

\footnotetext{
${ }^{1}$ As described by JA Wall, Jr, JB Stark and RL Standifer '('Mediation: A Current Review and Theory Development' (2001) Vol. 45, No. 3, $J$ Conflict Resol., 370) mediation goes back more than 1,000 years, being employed by Vikings in a similar manner as it is used today.

${ }^{2}$ For instance, according to M Liebman ('History and Overview of Mediation in the UK', in M Liebman (ed.), Mediation in Context (Jessica Kingsley, 2000) p 21), in England, the first steps towards the use of mediation can be traced to the 1970s in the form of conciliation for family disputes where in 1973, the Finer Committee proposed a "Family Court with a Conciliation Service attached to it to tackle the issues arising from separation and divorce'

${ }^{3}$ H Genn, S Riahi and K Pleming, 'Regulation of Dispute Resolution in England and Wales: A Sceptical Analysis of Government and Judicial Promotion of Private Mediation', in F Steffek and H Unberath (eds), Regulating Dispute Resolution ADR and Access to Justice at the Crossroads (Hart, 2013) p 138

4 CEDR, 'The Sixth Mediation Audit A survey of commercial mediator attitudes and experience', 22 May 2014, <http://www.cedr.com/docslib/TheMediatorAudit2014.pdf > accessed 5 January 2016

5 Legal Aid Statistics in England and Wales, July to September 2014, Published 18 December 2014 <https://www.gov.uk/government/uploads/system/uploads/attachment_data/file/388799/legal-aid-statistics-july2014-sept2014.pdf>, accessed 20 January 2015
} 
Contrary to England and Wales, other jurisdictions have opted to regulate the practice and procedures concerning mediation through a Mediation Act or by using conciliation methods that are quite similar to a mediation process. Such legal systems encompass different legal families, showing that the lack of regulation is not a feature of common law. Despite that, the English and Welsh approach is somewhat lacking when it comes to the rules governing mediation, leaving open questions such as how to proceed when something goes wrong, what to do when the mediator has no proper training, who can be a mediator and what are the limits to the appointment of a mediator? This article will examine the status of mediation in England and Wales with a particular focus on civil and commercial cases (and only touching upon family mediation as a contrast to the civil and commercial sphere), explaining how it has been employed without a regulatory statute. The article will further analyse if there is a need to regulate mediation in England and Wales and the possible outcomes of such regulation. First, a study of mediation will illustrate how mediation is regulated in different civil and common law jurisdictions; next, the focus will shift to an English and Welsh case study, presenting the current scenario and verifying if it is functional; and finally a conclusion will be drawn from the analysis made throughout the article.

\section{The regulation of mediation, an overview}

The traditional method to solve disputes has always been to bring a claim in the Court for a final binding decision. ADR is an alternative to access to justice supported by the judiciary. Under the range of dispute resolution mechanisms found in ADR, private disputes can be solved by a final binding decision or by a non-binding decision. ${ }^{6}$ Within the ADR family, mediation is a non-binding "consensual process in which a neutral third party helps others to negotiate a solution to a problem". ${ }^{7}$ Mediation has been regulated in different manners;

\footnotetext{
${ }^{6}$ P Brooker, Mediation Law (Routledge, 2013), p 4

${ }^{7}$ A Fiadjo, Alternative Dispute Resolution: A Developing World Perspective (Cavendish 2004) p 58
} 
sometimes a domestic law serves to specify the limits of private mediation but in other cases, it also establishes a judicial mediation. In this case, mediation defined as 'a private, confidential, consensual process in which a third-party neutral assists disputing parties to reach a settlement ${ }^{\prime 8}$ is similar to conciliation and can be defined as such. ${ }^{9}$ Therefore, the meaning of mediation and conciliation might be used interchangeably to demonstrate the approaches made by different legislations. To illustrate the dissimilar views, we first examine examples from civil law countries, followed by samples from common law nations, then show the European Union (EU) initiative and the recent United Nations Commission on International Trade Law (UNCITRAL) proposal for an international convention on mediation. The examples will not be exhaustive but they will elucidate the diverse views currently in place.

\subsection{Perspectives of civil law jurisdictions in which mediation is regulated}

The regulation of mediation in civil law countries has followed two styles: the first is to have an Act regulating mediation, and the second is to regulate it by inserting provisions about the topic into an existing code. The result is the same because provisions inserted in the Code require an Act determining such conduct. The legislations are relatively new - generally enacted within the last ten years - but there are exceptions such as Argentina that enacted its Mediation Act in $1995 .^{10}$ It was an Act on judicial mediation establishing compulsory mediation to take place before court proceedings, having the whole procedure managed by the courts. ${ }^{11}$ The rule was that once a claim was filed in court, a mediator was assigned to the case and he/she would schedule a hearing to start the mediation process. ${ }^{12}$ If the parties reached an

\footnotetext{
${ }^{8}$ Genn, Riahi and Pleming (n 3) p 156

${ }^{9}$ See for instance Article 1(3) of the UNCITRAL Model Law on International Commercial Conciliation that states: "[f]lor the purposes of this Law, "conciliation" means a process, whether referred to by the expression conciliation, mediation or an expression of similar import, whereby parties request a third person or persons ("the conciliator") to assist them in their attempt to reach an amicable settlement of their dispute arising out of or relating to a contractual or other legal relationship. The conciliator does not have the authority to impose upon the parties a solution to the dispute.'

${ }^{10}$ Ley 24.537 of 27 October 1995, titled Mediacion Y Conciliacion

${ }^{11}$ Article 1 stated: 'It is established a mandatory mediation prior to any trial, which shall be governed by the provisions of this law. This procedure will promote the direct communication between the parties to the settlement of the dispute.'

${ }^{12}$ Article 4 declares: 'The claimant will formalize its claim before the appropriate bureau of general reception of dossiers, detailing it in a form whose requirements shall be by way of regulations. Completion of the presentation will be followed by the draw of the mediator and the allocation of court that will be responsible for the law suit.'
} 
agreement, the mediator would inform the respective magistrate and in case of nonperformance, the execution of the agreement would continue in court. ${ }^{13}$ This law was modified in 2010 by a new act on mediation with the same objective, that is, compulsory mediation before court proceedings. ${ }^{14}$ This time, the new Act did not regulate a mediation procedure managed by courts; it regulated the compulsory pre-trial mediation that should occur in Argentina to be provided by private mediators registered and trained by the institutions assigned to accredit mediators. ${ }^{15}$ The Argentinian Law covers important aspects of mediation such as the types of disputes that can be submitted to mediation, ${ }^{16}$ the requirements to be a mediator ${ }^{17}$ and what happens if a party does not participate in the mediation proceeding. ${ }^{18}$ The Argentinian approach is to make mediation a pre-trial obligation, probably to promote such alternative methods of dispute resolution, therefore trying, at the same time, to reduce cases in courts. The idea is valid and it does make a suitable environment for mediation, but it is not a mediation resulting from the parties' freedom of contract. The parties do not have an option to select mediation as a method to solve their dispute, according to the law - it is imposed upon them. The reasons behind the regulation of mediation in Argentina are connected with the intention to modernise its legal system in order for it to be developed and efficient, giving people the opportunity to use alternatives methods of dispute resolution that will provide access to justice and reduce the overload of cases in the courts. ${ }^{19}$

\footnotetext{
${ }^{13}$ Article 12 declares: 'If an agreement is reached, such agreement will be registered at the hearing record signed by the mediator, the parties and the lawyers involved.' Article 14 also says: 'If an agreement is not reached through mediation, will be registered at the hearing record, a copy shall be delivered to the parties with the recorded result. In this case, the claimant will be able to start court proceedings, accompanying the records of the mediation.'

${ }^{14}$ Article 1 of the Ley 26589 of 15 April 2010, also titled Mediacion Y Conciliacion.

${ }^{15}$ Article 38 says: 'Training Entities. Training entities will be considered for the purposes of this law those public or private entities, singleended or plural-ended, dedicated in a total or partial to the education and training of mediators.' Article 39 states: 'Requirements of training entities. Training entities must be habilitated in accordance with the provisions contained in the regulations issued by the national executive.'

${ }^{16}$ Article 4 and 5 list the situations, for instance, it excludes criminal cases, divorce, cases involving a child, marriage annulment, adoptions, cases involving the Government in every level, insolvency and interdiction.

${ }^{17}$ Article 11 says that mediators need to be a lawyer with a minimum of three years of practice, have a mediation license issued by a regulated body, have been registered at the National Mediation Registration and demonstrate that he/she is an idoneous person.

${ }^{18}$ Articles 25 establishes that if a party does not participate in the mediation, voluntarily or involuntarily, the mediator will record the party's absence and the case will proceed in court. Articles 26 and 27 use the same approach as the old law, that is, if there is an agreement it can be enforced by courts and if no agreement is reached, proceedings shall start in court.

${ }^{19}$ E I Highton and G S Alvarez 'La Resolucion de Conflictos y la Mediacion en la Experiencia Argentina' (2000) Vol. 30, Cal. W. Int'1 L.J., 381, p 382
} 
Moving further north in the Americas, Mexico also regulated mediation through the Act on Mediation, Conciliation and Promotion of Social Peace in the State of Mexico. ${ }^{20}$ The Act's preamble delineates the reason for the regulation by stating that the law "should provide and regulate a dual system of alternative and restorative justice that effectively promotes the settlement of disputes and at the same time, promotes the culture of peace, forgiveness and restoration of interpersonal and social relations." Article 1 of the Act states that the law is of social interest and it has a public policy character, having among its objectives, besides the regulation of mediation, to 'promote a culture of peace and the restoration of the interpersonal and social relations, through means for the settlement of conflicts between the Mexican society'. ${ }^{21}$ In addition, Article 4 declares that ' $[\mathrm{t}]$ he Executive Branch through the Secretariat of Education of the Government of Mexico state, must include in the official educational programs, methods to promote the use, dialogue, negotiation, mediation, conciliation and restorative justice programs.' Combining Article 1 with Article 4, it can be concluded that the Mexican view is that mediation, among other methods of ADR, is directly connected to the promotion of peace as it leads the parties in a dispute to solve the impasse amicably. The Mexican Act defines mediation as the 'process in which one or more mediators intervene by facilitating the communication between the interested parties, in order for them to reach an agreement giving a full legal and satisfactory solution to the conflict' ${ }^{22}$ The Act also gives a definition to conciliation stating that it is the 'process in which one or more conciliators assist the parties by facilitating a dialogue and proposing legal, equitable and fair solutions to the conflict'. ${ }^{23}$ Conciliation here differs from mediation as the former promotes settlement by giving a non-binding legal solution to the quarrel and the latter endorses a dialogue so that the parties can reach an agreement. The Act regulates important subjects such as what are the

\footnotetext{
${ }^{20}$ Decreto 251 of 22 December 2010, titled Ley de Mediación, Conciliación y Promoción de la Paz Social para el Estado de México.

${ }^{21}$ Article 1, II

${ }^{22}$ Article 5, VII

${ }^{23}$ Article 5, VIII
} 
requirements to be a mediator, ${ }^{24}$ that the principles of confidentiality, impartiality, independence and honesty are core values of mediation, ${ }^{25}$ and that the statutory limitations for enforcing the agreements are reached through mediation. ${ }^{26}$

In Europe, three countries have recently adopted mediation acts: France enacted its regulation in 2011 while Spain and Germany did so in $2012 .{ }^{27}$ The proximity in the enactment of the legislation is owing to all three acts resulting from the implementation of the EU Directive 2008/52/CE to the countries' domestic law. Therefore, the same type of provisions can be found in each instrument, such as all three statutes having the Directive's definition of mediation. ${ }^{28}$ All three countries used the opportunity of implementation of an EU Directive on cross-border mediation to regulate the domestic law. ${ }^{29}$ The motivation to regulate mediation in France, Spain and Germany comes from the reasons why the EU directive was implemented, that is, to provide a better access to justice by creating judicial and extrajudicial forms of dispute resolution. Additionally, mediation is a cost-effective process and once parties have reached an agreement through mediation, they "are more likely to be complied with voluntarily and are more likely to preserve an amicable and sustainable relationship". ${ }^{30}$

In Germany for instance, on the Directive's adoption, the Mediation Act covered the main aspects of mediation such as mediator's obligations, ${ }^{31}$ conflict of interest,${ }^{32}$ confidentiality and training requirements. ${ }^{33}$ The Act also inserted into the Code of Civil Procedure provisions

\footnotetext{
${ }^{24}$ Article 13

${ }^{25}$ Article 20

${ }^{26}$ Article 48

${ }^{27}$ In Spain, Real Decreto-Ley 5/2012 of 06 July 2012, titled Mediación en Asuntos Civiles y Mercantiles. In France, Ordonnance ${ }^{\circ} 2011-$ 1540 of 16 November 2011, titled Ordonnance $\mathrm{n}^{\circ}$ 2011-1540 du 16 novembre 2011 portant transposition de la directive 2008/52/CE du Parlement européen et du Conseil du 21 mai 2008 sur certains aspects de la médiation en matière civile et commercial and in Germany an Act of 21 July 2012 titled Gesetz zur Förderung der Mediation und anderer Verfahren der außergerichtlichen Konfliktbeilegung

${ }^{28}$ The Directive in Article 3 (a) states: "Mediation" means a structured process, however named or referred to, whereby two or more parties to a dispute attempt by themselves, on a voluntary basis, to reach an agreement on the settlement of their dispute with the assistance of a mediator. This process may be initiated by the parties or suggested or ordered by a court or prescribed by the law of a Member State.' A similar concept is found in France (see Article 21 of the Loi $\mathrm{n}^{\circ}$ 95-125 du 8 février 1995 relative à l'organisation des juridictions et à la procédure civile, pénale et administrative which was modified by the Ordonnance $\mathrm{n}^{\circ} 2011-1540$ ), in Spain (see article 1 of the Real DecretoLey 5/2012) and in Germany (Article 1 of the Gesetz zur Förderung der Mediation und anderer Verfahren der außergerichtlichen Konfliktbeilegung)

${ }^{29}$ B Hess and N Pelzer, 'Regulation of Dispute Resolution in Germany: Cautious Steps towards the Construction of an ADR System', in F S and H Unberath (eds), Regulating Dispute Resolution ADR and Access to Justice at the Crossroads (Hart, 2013) p 222

${ }^{30}$ Directive 2008/52/EC of 21 May 2008, preamble 7.

${ }^{31}$ Section 2

32 Section 3

${ }^{33}$ Section 4 and 5
} 
concerning the conciliation judge (Güterichter), which is a person performing a similar role to the mediator in Argentina, that is, he/she will preside over the conciliation hearing preceding a trial. ${ }^{34}$ According to Section 278(5) of the Code of Civil Procedure, the conciliation judge 'may avail himself of all methods of conflict resolution, including mediation'. In addition, Section 278a of the same Code states that the court may suggest the use of mediation and if that path is adopted by the parties, 'the court shall order the proceedings stayed'. A similar situation occurred in Spain when it implemented the EU Directive but it also created some domestic norms. Article 2 of the Spanish Act excludes the application of the law to criminal mediation, administrative mediation, employment mediation and consumer mediation. Article 11(2) requires the mediator to have a university degree and a mediation qualification and Article 11(3) demands that the mediator has insurance to cover any damages caused while acting as a mediator.

The French approach is similar to the Spanish and the German views. In France judicial mediation has been regulated by the French Code of Civil Procedure since $1995 .{ }^{35}$ Article 1311 of the Code of Civil Procedure declares that

[a] judge seized of litigation may, after having obtained the consent of the parties, appoint a third person who will hear them and confront their points of view to help them resolve the dispute dividing them. This power is also given to the summary procedure judge in the course of the proceeding.

The Code, among other subjects, determines that the mediation cannot be longer than three months,${ }^{36}$ the requirements to be a mediator, ${ }^{37}$ when the mediator receives payment for the job performed $^{38}$ and the effects of the agreement reached through mediation. ${ }^{39}$ With the implementation of the EU Directive, France presented regulation on private mediation

\footnotetext{
${ }^{34}$ Section 278 (2) of the German Code of Civil Procedure

${ }^{35}$ F Ferrand, 'Regulation of Dispute Resolution in France: Evolutions and Challenges', in F S and H Unberath (eds), Regulating Dispute Resolution ADR and Access to Justice at the Crossroads (Hart, 2013) p 179

${ }^{36}$ Article 131-4

${ }^{37}$ Article 131-5

${ }^{38}$ Article 131-13

${ }^{39}$ Article 131-12
} 
unrelated to court proceedings. As a result, a new book was introduced to the Code of Civil Procedure titled 'The Amicable Settlement of Differences' (La résolution amiable des différends $)^{40}$ with provisions regarding the conventional mediation and conciliation process. ${ }^{41}$

Civil law countries, following the need to have written law, are inclined to regulate mediation. Perhaps, culturally, in civil law countries, it would be strange to accept certain aspects of mediation being regulated by a simple agreement between the parties to mediate their dispute. It seems that there needs to be an agent or an institution overseeing the practice of mediation.

\subsection{Perspectives of common law jurisdictions in which mediation is regulated}

Just as with civil law jurisdictions, some common law jurisdictions have decided to regulate mediation through a mediation act. The provisions can be similar, especially in relation to the regulation of the mediators' profession. As seen above, the acts contain a provision on what is necessary to be a mediator in addition to the need to have some organisation overseeing the profession within a country. The norms in common law countries do not embody the same level of detail that can be found in a civil law country, although the rationale found in the legislations is quite similar.

In Australia, the use of mediation dates back to the 1980s when community justice centres in New South Wales adopted such a method of dispute resolution. ${ }^{42}$ Its Mediation Act is dated 1997 and it is quite short, having only 13 sections. The short title ${ }^{43}$ is followed by establishing its commencement and its interpretation. ${ }^{44}$ In the final part, the Act demonstrates its purpose by defining the term 'approved agency' as 'a body or an organisation declared by the

\footnotetext{
${ }^{40}$ Book V

${ }^{41}$ Articles 1530 to 1541

${ }^{42}$ N Alexander, 'Mediation in Practice: Common Law and Civil Law Perspectives Compared' (2001) 6 Int'l. Trade \& Bus. L. Ann. 1, 2. Also, see Community Justice Centres Act 1983, Section 20a.

${ }^{43}$ Section 1

${ }^{4}$ Sections 2 and 3
} 
regulations to be an approved agency for the purposes of this Act' ${ }^{45}$ The approved agency is the organisation overseeing the mediators' profession and, according to the Act, mediators must be registered with an approved agency. ${ }^{46}$ The law focuses mainly on the process of mediator accreditation, explaining how they are registered, ${ }^{47}$ the duration of the registration, ${ }^{48}$ the registration's renewal ${ }^{49}$ and the registration's cancellation. ${ }^{50}$ It also addresses the duty to not disclose information obtained through mediation" ${ }^{51}$ and that a mediator is entitled to "the same protection and immunity as a judge of the Supreme Court'.52 A particular feature of the Act relating to the mediation process can be found in its Section 9, which determines that evidence produced in mediation could not be used in other proceedings. ${ }^{53}$ The purpose of the legislation is to regulate the practice of mediators by clarifying the mediation process, it "establishes standards of competency, including minimum qualifications and an approval process or registration scheme". ${ }^{54}$ As a result the law guarantees the rights and duties of the parties mediating, the mediators and third parties. The Australian Mediation Act is succinct but there are other instruments regulating mediation in Australia. For instance, the Community Housing Providers (National Law) (South Australia) Act 2013 makes room for a courtconnected mediation when an application has been made to the Appeal Tribunal. The Tribunal has the power to decline to hear the matter in dispute if it finds that 'the applicant should have sought to resolve the matter through a mediation or conciliation process ${ }^{55}$ Moreover, the Farm Debt Mediation Act 1994 provides that a farmer cannot be a party to an enforcement action derived of a mortgage 'until notice of availability of mediation is given'. ${ }^{56}$

\footnotetext{
${ }^{45}$ Section 3(1)

${ }^{46}$ Section 5. The Act does not regulate the approved agencies, this was left to the Executive, see Section 13 (1) and 13(2)(b) of the Mediation Act

${ }^{4}$ Section 5

${ }^{48}$ Section 6

${ }^{49}$ Section 7

${ }^{50}$ Section 8

${ }^{51}$ Section 10

${ }^{52}$ Section 12

${ }^{53}$ The Section creates an exception that is the list of possibilities under Section 131 of the Evidence Act 1995 of the Commonwealth

54 Robyn Carroll. 'Shaping ADR through legislative instruments' (2002) Vol. 5, No. 5, ADR Bulletin, 78, p 79, in <http://epublications.bond.edu.au/adr/vol5/iss5/5>, accessed on 17.04.2016

${ }^{55}$ Schedule 2(3)(b)

${ }^{56}$ Section $8(1)$
} 
In Canada, the province of Ontario regulates mediation in its rules of civil procedure and in a Mediation Act. The rules of civil procedure provide that civil actions that are subject to case management will be the object of mandatory mediation. ${ }^{57}$ The regulation is made of two rules, one general ${ }^{58}$ and one specific for estates, trusts and substitute. ${ }^{59}$ The generic rule declares that the purpose of mediation is "reduce cost and delay in litigation and facilitate the early and fair resolution of disputes." ${ }^{\prime 60}$ It also states that the in the mediation process "a neutral third party facilitates communication among the parties to a dispute, to assist them in reaching a mutually acceptable resolution." ${ }^{61}$ From the wording of the rules of civil procedure it can be concluded that the theory behind the regulation of mediation lies on the general view that mediation provides for a faster dispute resolution method in which the parties will come to a settlement. The rules of civil procedure regulate the mediation process but not the profession of mediation. ${ }^{62}$ The province of Ontario also adopted a succinct Mediation Act with 17 sections. The Ontario Commercial Mediation Act 2010 was based on the UNCITRAL Model Law on International Commercial Conciliation $(2002)^{63}$ and it applies solely to mediation for the settlement of commercial disputes. ${ }^{64}$ Notwithstanding that the Act derives from the Model Law, the concept of mediation adopted by the Act is not exactly the same as the Model Law. ${ }^{65}$ The Act defined mediation as a collaborative process in which, (a) the parties to a commercial dispute agree to request a neutral person, referred to as a mediator, to assist them in their attempt to reach a settlement

\footnotetext{
57 "Case management is a system in which the court supervises cases and imposes strict timelines on their movement through the pretrial and trial process. Certain civil actions, such as family law cases, are excluded from mandatory mediation." Ministry of the Attorney General 'Public Information Notice - Ontario Mediation Program', <https://www.attorneygeneral.jus.gov.on.ca/english/courts/manmed/notice.php >, accessed 19 April 2016

${ }^{58}$ Rule 24.1

${ }^{59}$ Rule 75.1

${ }^{60}$ Rule 24.1.01

${ }^{61}$ Rule 24.1 .02

${ }^{62}$ For instance, the rules regulate: the establishment of mediation committees (rule 24.1.07), the list of mediators (rule 24.1.08), the mediation session (rule 24.1.09), what happens if parties do not attend the mediation session (rule 24.1.12) and the outcome of mediation (rule 24.1.15).

${ }^{63}$ Section 4

${ }^{64}$ Section 1

${ }^{65}$ The Model Law uses the terms conciliation and mediation interchangeably
} 
in their dispute, and (b) the mediator does not have authority to impose a solution to the dispute on the parties. ${ }^{66}$

The statue covers the commencement and termination of mediation, ${ }^{67}$ the appointment of the mediator, ${ }^{68}$ the duty to disclose possible conflicts of interest ${ }^{69}$ and the mediation process (the conduct of the mediator, the mediator's authority and the duty to keep the information confidential). ${ }^{70}$ The Act also regulates the enforcement in courts of the agreement obtained through mediation ${ }^{71}$ and the use of parallel proceedings between mediation and arbitration. If such case occurs, the Act specifies that the commencement of the arbitration does not necessarily mean that the mediation has ended. ${ }^{72}$ The rationale of such provision can be supported by the fact that there might be a statutory limitation to start arbitration; however, the commencement of arbitration would give a strong presumption that one of the parties does not want to proceed with mediation, unless this is part of what would be an expensive litigation strategy.

Another recent example of mediation law is the Malaysian Mediation Act 2012. In its preamble, the Act establishes that the purpose of the regulation is to promote mediation by "facilitating the parties in disputes to settle disputes in a fair, speedy and cost-effective manner and to provide for related matters." The Act applies only to private mediation, excluding courtconnected mediation and mediation conduct by the Legal Aid Department. ${ }^{73}$ It defines mediation as the 'voluntary process in which a mediator facilitates communication and negotiation between parties to assist the parties in reaching an agreement regarding a dispute'.74 The Act covers topics such as the commencement of mediation, ${ }^{75}$ the appointment of the

\footnotetext{
${ }^{66}$ Section 3

${ }^{67}$ Section 5

${ }^{68}$ Section 6

${ }^{69}$ Ibid.

${ }^{70}$ Sections 7 and 8

${ }^{71}$ Section 13

${ }^{72}$ Section 11(3)

73 Section 2

${ }^{74}$ Section 3

${ }^{75}$ Section 5
} 
mediator, ${ }^{76}$ the conduct of mediation, ${ }^{77}$ the duty of confidentiality ${ }^{78}$ and the effects of a settlement agreement made through mediation. ${ }^{79}$ The Act provides that the mediation agreement shall be in writing and it needs to contain

an agreement by the parties to submit mediation disputes which have arisen or which may arise between them, the appointment of a mediator, the costs to be borne by the parties and other matters the parties deem appropriate. ${ }^{80}$

The mediation agreement under the Malaysian law does not prevent the parties starting a civil action in court or through arbitration. ${ }^{81}$ It is as if the agreement to mediate would be a promise that if a dispute arises, the parties will try to mediate but it is at the parties' discretion to pursue mediation.

The common law view shows that despite the case law system, the statutes on mediation regulate several aspects of this alternative method of dispute resolution. The practice of drafting legislation on mediation in common law, as shown by the Australian example, is not novel, demonstrating that the regulation of mediation can be a standard system made by either common law or civil law jurisdictions.

\subsection{EU Directive on Mediation of Civil and Commercial matters}

Cross-Border civil and commercial mediations within the EU are regulated by Directive 2008/52/EC of 21 May 2008 on certain aspects of mediation in civil and commercial matters. The European Commission's Green Paper in 2002 on alternative dispute resolution for civil and commercial matters sought to understand the use of ADR and what could be done to encourage and promote the further use of mediation. ${ }^{82}$ The paper identified ADR 'as a political

\footnotetext{
${ }^{76}$ Section 7

77 Section 11

${ }^{78}$ Section 15

${ }^{79}$ Section 14

${ }^{80}$ Section 6(3)

81 Section 4

${ }^{82}$ Commission of the European Communities, Green Paper on alternative dispute resolution in civil and commercial law (Commission of the European Communities 2002) COM (2002) 196 Final
} 
priority and specifically identified cross-border disputes as an area ripe for regulation. ${ }^{83}$ Among the issues to be considered for mediation regulation was enforcement of mediation agreements, the quality of mediator training, accreditation and a change in the limitation periods for parties attempting mediation. The purpose of the Cross-Border Directive is to ensure that mediation is utilised as an ADR tool to save court time and money in order to settle disputes prior to trial owing to an overload of cases in Court ${ }^{84}$. The Cross-Border Directive's objective:

is to facilitate access to alternative dispute resolution and to promote the amicable settlement of disputes by encouraging the use of mediation and by ensuring a balanced relationship between mediation and judicial proceedings ... [and] shall apply, in crossborder disputes, to civil and commercial matters. ${ }^{85}$

Therefore, the objective of the Cross-Border Directive is not to compel parties to enter into mediation but instead to govern the principles, quality and standards of mediation to ensure that parties are able to enter into mediation knowing that a certain level of quality will be maintained. These rules only govern mediations that are cross-border between parties where at least one party is domiciled or habitually resident in a Member State. The Cross-Border Directive seeks to maintain the quality of mediation by encouraging Member States to develop a voluntary code of conduct and ensure that mediators adhere to such a code. There is encouragement to train mediators so they are competent, effective and impartial. ${ }^{86}$ The CrossBorder Directive seeks to maintain the flexible and voluntary nature of mediation while facilitating the national courts to request that parties attend mediation to resolve their dispute, so long as a claim has been lodged with the national court. This does not, however, seek to

\footnotetext{
${ }^{83}$ S White, 'Directive 2008/52 on certain aspects of mediation in civil and commercial matters: a new culture of access to justice?' (2013) 79 (1) Arbitration, 52, 53

${ }^{84}$ G De Palo, L D'Urso, M Trevor, B Branon, R Canessa, B Cawyer, R Florence, 'Rebooting' The Mediation Directive: Assessing the limited impact of its implementation and proposing measures to increase the number of mediations in the EU, (Directorate General for Internal Policies) (2014) <http://www.europarl.europa.eu/RegData/etudes/etudes/join/2014/493042/IPOL-JURI_ET(2014)493042_EN.pdf>

${ }^{85}$ European Parliament, Directive 2008/52/EU of the European Parliament and the Council on certain aspects of mediation in civil and commercial matters [2008] OJL 136/3, articles 1 and 2

${ }^{86}$ European Parliament, Directive 2008/52/EU of the European Parliament and the Council on certain aspects of mediation in civil and commercial matters [2008] OJL 136/3, article 4
} 
impose compulsory mediation and does not take precedence over any national legislation of the Member State but allows the parties to ensure that their use of mediation can be effective.

The Cross-Border Directive was transposed into the UK in 2011 in the form of the CrossBorder Mediation (EU Directive) Regulations 2011 (the Cross-Border Regulations). These Regulations replicate the Cross-Border Directive by applying the key principles of mediation to cross-border civil and commercial disputes between Member States. The key principles are: to provide a quick and cost-effective alternative to litigation; to ensure a certain level of quality for meditators and mediator organisations; to maintain and ensure adherence to a code of conduct; to allow the courts to suggest that parties mediate without compelling them to do so; to make mediation agreements enforceable; and to maintain confidentiality.

Many of the above key elements are already found in commercial mediators' dealings and in the providers' procedures that provide for effective self-regulation, including their codes of conduct and accreditation schemes of the industry in England and Wales. As there is a close nexus between existing forms of self-regulation and the Cross-Border Directive, the latter might readily provide a basis for domestic regulation of commercial mediation in England and Wales.

In 2016, the European Commission will undertake a review of the application of the CrossBorder Directive (for those Member States who signed up to it) to assess the impact and use of mediation under it. ${ }^{87}$ Possibly some changes and improvements to the terms of the CrossBorder Directive will occur as a result of this or, alternatively, if the results are positive it may encourage further EU legislation for the regulation of mediation between domestic parties and not just cross-border.

It should be noted that regulation for different types of mediation is gaining ground. For example, on 21 May 2013 the European Parliament and Council implemented Directive

\footnotetext{
${ }^{87}$ Directive 2008/52/EU of the European Union and the Council on certain aspects of mediation in civil and commercial matters [2001] OJL 136.6, article 11
} 
2013/11/EU on alternative dispute resolution for consumer disputes (Directive on consumer ADR) and Regulation (EU) No 524/2013 on online dispute resolution for consumer disputes (Regulations on consumer Online Dispute Resolution). Such instruments aim at optimising the facilities available to dispute settlements between business and consumers. This conduct should be welcomed, especially in regard to online disputes, as it will provide a more effective method of dispute resolution.

\subsection{UNCITRAL's proposal}

In addition to the regional effort made by the EU, UNCITRAL has recently shown that it might adhere to the trend of harmonising mediation law. In the UNCITRAL's report on its 47th session that took place in July $2014,{ }^{88}$ the part relating to future projects mentioned support for work in the area of 'enforcement of international settlement agreements' ${ }^{89}$ The debate centred on the fact that agreements achieved in conciliation are difficult to enforce. The Commission argued that such settled agreements can be enforced as a contract between the parties; however, in cross-border contract law, such enforcement is not as easy as it may seem. Thus, 'it was said that the lack of easy enforceability of such contracts was a disincentive to commercial parties to mediate' ${ }^{90}$

As a result, the proposal was that a working group should develop a multilateral convention on the enforceability of international commercial settlement agreements reached through conciliation, with the goal of encouraging conciliation in the same way that the New York Convention had facilitated the growth of arbitration. $^{91}$

Some concerns were raised in relation to the feasibility of such endeavour. ${ }^{92}$ Nevertheless, the Commission decided that the working group should consider the proposal and would report

\footnotetext{
${ }^{88}$ UNCITRAL, 'Report of the United Nations Commission on International Trade Law Forty-seventh session' (7-18 July 2014) A/69/17.

${ }^{89}$ Ibid., para. 123

90 Ibid.

${ }^{91}$ Ibid.

92 Ibid., para. 124. The report aligned the following reasons: '(a) whether the new regime of enforcement envisaged would be optional in nature; (b) whether the New York Convention was the appropriate model for work in relation to mediated settlement agreements; (c) whether
} 
on the possibility of the project in the next meeting. ${ }^{93}$ This is just a first step in a long dialogue to be held by UNCITRAL and perhaps the proposal might not even move forward. Yet, the idea is blooming and the possibility that mediation agreements will enjoy a similar application as an arbitral award should be welcomed. Having an agreement made through mediation in a cross-border dispute that cannot be enforced in a different jurisdiction from where the agreement was reached makes the use of mediation ineffective, because the risk of high costs are eminent. Preventing such a situation could be essential for the promotion of international mediation.

\section{The English and Welsh scenario}

Currently, domestic mediation in England and Wales is not regulated in the same way as demonstrated above, that is, there is no Mediation Act. However, there is growing support for mediation, as will be seen from the case law referred to below. While mediation is becoming the popular avenue for ADR and there is growing judicial support for it, does this mean that mediation should be regulated in England and Wales? The overriding objective of the English and Welsh legal system is to ensure that cases are dealt with justly, in a cost-effective and proportionate manner. ${ }^{94}$ Nevertheless, courts have championed mediation for more than a decade, as can be seen from the case of Hurst $v$ Leeming. ${ }^{95}$ This judgment shows a steadfast determination that although mediation is not compulsory 'alternative dispute resolution is at the heart of today's civil justice system ${ }^{96}$ and proper consideration should be given when deciding whether or not to mediate. Lightman J went on to comment that '[w] hat appears to be

\footnotetext{
formalizing enforcement of settlement agreements would in fact diminish the value of mediation as resulting in contractual agreements; (d) whether complex contracts arising out of mediation were suitable for enforcement under such a proposed treaty; (e) whether other means of converting mediated settlement agreements into binding awards obviated the need for such a treaty; and (f) what the legal implications for a regime akin to the New York Convention in the field of mediation might be.'

${ }_{93}$ Ibid., paragraph 129. After the 47th meeting the debated continued and in the UNCITRAL, 'Report of the United Nations Commission on International Trade Law Forty-ninth session' (7-11 September 2015) A/CN.9/861 the Working Group II the debate over a possible instrument is taking shape but for now, UNCITRAL will only draft provisions of a future instrument

${ }^{94}$ R Jackson, IR Scott, SD Whitaker et al., Civil Procedure Rules 2013 (Sweet and Maxwell 2013)

${ }^{95}$ Hurst v Leeming [2001] EWHC 1051 (Ch)

${ }^{96}$ Ibid., para. 10
} 
incapable of mediation before the mediation process begins often proves capable of satisfactory resolution later' ${ }^{97}$ Mediation is supported not only because it is a cost-effective alternative to litigation, but mediation is capable of achieving much more by way of a resolution than as catered by the courts. For example, frequently in commercial matters, the court can only give a judgment in financial terms (unless a specific remedy is sought such as an injunction or a declaration). Whereas through mediation the parties might opt for part financial settlement and some non-financial element, such as a further work opportunity. This is an inherent feature in the England and Wales civil litigation system where the majority of the Civil Procedure Rules $(\mathrm{CPR})$ relate to ensuring costs in claims are proportionate, costs are budgeted and dealt with justly at the end of a case..$^{98}$

The cultivation of mediation has continued apace since Hurst $v$ Leeming. In Dunnett $v$ Railtrack $\mathrm{Pl}^{99}$ the Court of Appeal further emphasised the overriding objective of the CPR by postulating that not only did the court have an obligation to further the overriding objective but both the parties to the proceedings had a duty to do the same. This case was one of the first examples where the judiciary introduced the notion that parties who dismiss off-hand a reasonable request to mediate would be likely to 'face uncomfortable costs consequences'. ${ }^{100}$ The effect of this judicial opinion, albeit an obiter dictum remark, is that mediation remains a voluntary process but with the potential for severe costs penalties if a party simply dismisses off-hand the invitation to mediate. Costs are also applicable if the parties withdraw from the mediation at the eleventh hour, despite the appointed mediator viewing the case as appropriate for mediation, as was discovered in the case of Leicester Circuits Ltd v Coates Brothers Plc. ${ }^{101}$ The courts were using the CPR's overriding objective as a tool to encourage parties to resolve their disputes through ADR - and in particular, mediation - otherwise unreasonable refusals

\footnotetext{
${ }^{97}$ Ibid., para. 13

${ }^{98}$ See CPR Rule 1,3 and 44

${ }^{99}$ Dunnett v Railtrack Plc [2002] EWCA Civ 303

${ }^{100}$ Ibid., para. 15

${ }^{101}$ Leicester Circuits Limited v Coates Brothers Plc [2003] EWCA Civ 333, 13
} 
would result in costs sanctions upon the party refusing, even if they were ultimately successful in the litigation claim.

The judicial views in the cases above led to the Court of Appeal setting authority for when a court can impose costs sanctions on a party who unreasonably refuses to mediate, as in the case of Halsey $v$ Milton Keynes General NHS Trust. ${ }^{102}$ This case specifically identifies mediation as the ultimate ADR tool although the judgment does not diminish other forms of ADR. The ruling actively encourages mediation and makes it abundantly clear that mediation is and will remain a voluntary process. Accordingly, the court will not compel parties to mediate as the effectiveness of mediation arises, not from the compulsion but by being entered into willingly by the parties. Halsey sets out certain factors, which should be considered when assessing whether to penalise a successful party in relation to costs for unreasonably refusing to mediate. These factors include the nature of the dispute; merits of the case; other ADR methods that have been considered; whether mediation costs would be disproportionately high; delay; and whether mediation would have reasonable prospects of success. These criteria allow the court to have a more rounded and considered approach when considering whether to depart from the usual rules on awarding costs. Additionally, voluntary mediation in courts have a statutory character when it comes to small claims court. Rule $26.4 \mathrm{~A}$ of the CPR declares that when parties commence proceedings in small claims courts they can indicate that they would like the claim to be referred to the mediation service. ${ }^{103}$ Here the law provides for a pre-trial mediation but such conduct has to be indicated by the parties. Thus, as opposed to the examples

\footnotetext{
${ }^{102}$ Halsey v Milton Keynes General NHS Trust [2004] EWCA (Civ) 576; The precedent set out in Halsey above has been actively followed by the Courts such as in Burchell v Bullard \& Others [2005] EWCA Civ 358; Rolfv De Guerin [2011] EWCA Civ 78; Swain Mason \& Others v Mills and Reeve (a firm) [2012] EWCA Civ 498 and Colin Wright v Michael Wright Supplies Ltd and Turner Wright Investments Ltd.[2013] EWCA Civ 234; and most recently in Laporte \& Christian v The Commissioner of Police of the Metropolis [2015] EWHC 371 (QB)

103 The rule says: Referral to the Mediation Service 26.4A (1) This rule applies to claims started in the County Court which would normally be allocated to the small claims track pursuant to rule 26.6. (2) This rule does not apply to- (a) road traffic accident, personal injury or housing disrepair claims; or (b) any claim in which any party to the proceedings does not agree to referral to the Mediation Service. (3) In this rule, 'the Mediation Service' means the Small Claims Mediation Service operated by Her Majesty's Courts and Tribunals Service. (4) Where all parties indicate on their directions questionnaire that they agree to mediation, the claim will be referred to the Mediation Service. (5) If a claim to which this rule applies is settled, the proceedings will automatically be stayed with permission to apply for- (a) judgment for the unpaid balance of the outstanding sum of the settlement agreement; or (b) the claim to be restored for hearing of the full amount claimed, unless the parties have agreed that the claim is to be discontinued or dismissed.
} 
mentioned above regarding other jurisdictions, for small claims there is a non-compulsory option to mediate before any trial.

While mediation in England and Wales continues to enjoy judicial support, and the courts can impose costs consequences for parties who do not reasonably undertake mediation or a form of ADR, it can, in limited circumstances, lift the confidential veil on mediation. ${ }^{104}$ What more, if anything, exists in terms of regulation for an industry that receives such high praise and encouragement?

In England and Wales, mediators are either accredited or not. The majority of accredited mediators are trained through one of a number of training organisations offering approved and/or accredited training schemes. ${ }^{105}$ The accrediting bodies often have their own code of conduct - which echoes the EU Code of Conduct for Mediators - and there are minimum standards that need to meet by those wishing to train as mediators before they are accredited or registered. ${ }^{106}$ These professional organisations require impartiality, neutrality, a mediation agreement, confidentiality, avoidance of conflicts, ensuring that the mediator is sufficiently trained to undertake the mediation, and that the mediator continues with professional development. This acts as a form of self-regulation, at least for those who are accredited. As such, there may be little or no need to regulate commercial mediation in England and Wales because such codes exist within the accrediting bodies, which should be sufficient in the ordinary course of business.

Moreover, even when certain aspects of mediation are mandatory, the law left its regulation to professional bodies. Family mediation provides one example of how such a method works which differs from civil and commercial cases. Similar to civil law countries, a procedure for

\footnotetext{
${ }^{104}$ Farm Assist Limited (in liquidation) v The Secretary of State for the Environment, Food and Rural Affairs (No.2) [2009] EWHC 1102 (TCC)

${ }^{105}$ For example the Standing Conference of Mediation Advocates provides mediator training courses which have been accredited by the Civil Mediation Council < http://www.mediationadvocates.org.uk/117/> accessed 26 April 2015

${ }^{106}$ For example, the Civil Mediation Council requires those who wish to sign up to be registered mediators with them, require them to undertake a CMC recognised registered mediator training course and observe three mediations before they are eligible for being a CMC registered mediator; < http://www.civilmediation.org/join-cmc/36/individuals> accessed 1 July 2015
} 
mediation in court was established by law. The Children and Families Act 2014, in Section 10 (1) declares that '[b]efore making a relevant family application, a person must attend a family mediation information and assessment meeting'. The Act determined that the Family Procedure Rules would regulate the mediation information and assessment meetings (MIAM). ${ }^{107}$ The rules provide that courts must take into account, in every stage of the proceedings, if the noncourt dispute resolution is appropriate. ${ }^{108}$ In making such consideration, the court must ensure that a MIAM took place, whether a valid MIAM exemption was claimed or mediator's exemption was confirmed; and whether the parties attempted mediation or another form of non-court dispute resolution and the outcome of that process. ${ }^{109}$ Once the court concludes that non-court dispute resolution is appropriate, it will adjourn the proceedings and enable the parties to obtain information and advice about, and consider using, non-court dispute resolution; and where the parties agree, to enable non-court dispute resolution to take place. ${ }^{110}$ To conduct a MIAM, the mediator has to be an authorised family mediator. According to the Family Procedure Rules, this person has to be identified by the Family Mediation Council. ${ }^{111}$ The Council

acts as a common platform for family mediation's national organisations to negotiate with government and other stakeholders ... [and they guarantee that their] members are the national family mediation organisations in England and Wales, all of which ensure their family mediators work to the professional and training standards outlined in our constitution. ${ }^{112}$

As a result, there is a piece of legislation imposing an element of family mediation but its regulation of the mediators is left to professional bodies. However, not all mediators are

\footnotetext{
${ }^{107}$ Children and Families Act 2014, Section 10 (2)

${ }^{108}$ Family Procedure Rules, Part 3, Chapter 2, 3.3 (1)

${ }^{109}$ Family Procedure Rules, Part 3, Chapter 2, 3.3 (2) (a)(b)(c)

${ }^{110}$ Family Procedure Rules, Part 3, Chapter 2, 3.4 (1) (a)(b)

${ }^{111}$ Family Procedure Rules, Part 3, Chapter 1, 3.1

${ }^{112}$ In <http://www.familymediationcouncil.org.uk/us/ > accessed 22 January 2016
} 
accredited or trained through these bodies; therefore, is there a need for external regulation of domestic mediation?

\section{The lack of regulation in English and Welsh law - is it functional?}

The lack of regulation in England and Wales must be functional as the industry has grown without it. However, as the industry continues to boom, mediation is becoming more popular and more professionals are seeking to become mediators as an independent profession. Thus, will the lack of regulation enable the industry to continue to be functional and sustainable? In answering such question, three points must be addressed: first, do mediators want regulation; second, what would be the ramifications (both positive and negative) of a regulatory framework; and last, how will mediation agreements be enforced?

\subsection{Do mediators want regulation?}

Since the Woolf Reforms, the Jackson costs review and amendments in the CPR encouraged lawyers to actively use ADR. ${ }^{113}$ There are a number of ADR processes that are used today: '[o]f all of these processes, mediation and arbitration are most common and are well established and sit parallel to the legal and judicial framework in England and Wales.' ${ }^{114}$ As mediation has grown and professional bodies have developed codes of conduct and imposed accreditation schemes there is a de facto self-regulation for each body. Therefore, is there a need or a desire in industry to regulate commercial mediation activities in England and Wales?

In 2011 the Ministry of Justice published a consultation paper in relation to resolving disputes in the County Courts. ${ }^{115}$ ADR, including mediation, was a focal point for a number of

\footnotetext{
${ }^{113}$ H Woolf, Access to Justice - Final Report (Department of Constitutional Affairs, 1996). In the early 1990s Lord Woolf undertook a review of access to justice in the United Kingdom Courts System and in 1996 published his Access to Justice Report. This concentrated on the reformation of the Civil Procedure and saw the publication of the Civil Procedure Rules, which encourage the use of ADR. The purpose of the Woolf reforms was to make the litigation process more open, to speed up the process, reduce costs and encourage the early resolution to disputes

${ }^{114}$ Ministry of Justice, 'Solving disputes in the county courts: creating a simpler, quicker and more proportionate system: A Consultation on reforming civil justice in England and Wales' (The Stationery Office Limited Consultation Paper CP6/2011 March 2011) 39 http://www.justice.gov.uk/downloads/consultations/solving-disputes-county-courts.pdf> accessed 14 November 2012 115 Ibid.
} 
the questions and the explanatory text hailed the Civil Mediation Council (CMC) and its accreditation scheme for its unique position in the mediation industry. ${ }^{116}$ The very evident expansion of mediation as a solution for resolving disputes outside of the court has led the Ministry of Justice to question whether regulation should be required. Focusing on the CMC, the consultation sought opinions on whether 'the CMC's accreditation scheme for mediation providers is sufficient?' and 'if ... no, what more should be done to regulate civil and commercial mediators?' ${ }^{117}$ There was a divided response to these important questions. No doubt this was partly owing to the number and diversity of mediation organisations providing training and accreditation services, but also because there are practising mediators who are not accredited by any professional body.

In fact the response to this consultation showed that $57 \%$ of respondents deemed that the CMC's accreditation scheme to be sufficient, leaving $43 \%$ disagreeing. ${ }^{118}$ Although the majority of respondents agreed that the CMC's accreditation scheme was suitable, approximately $24 \%$ out of the $57 \%$ indicated that 'a number of changes and amendments were required to the scheme either now or in the future, especially in light of the proposals being made to increase the use of mediation'. ${ }^{119}$ Furthermore, those respondents who stated that the CMC's accreditation scheme was sufficient, went beyond this and expressed the view that the it would need 'evolutionary development' ${ }^{\prime 20}$ to stay abreast of the changing market and increasing public awareness of the industry. It was thought that a central accreditation scheme would create clearer standards across the profession, as there currently exists potential for confusion in the market between accredited and non-accredited mediators and the minimum standards required. Although the majority of respondents viewed the CMC's accreditation

\footnotetext{
${ }^{116}$ The Civil Mediation Council is an organisation that promotes and provides minimum standards for mediation in England and Wales for those who are accredited with them. Ibid., para. 139

${ }^{117}$ Ministry of Justice (n 101), 43

${ }^{118}$ Ministry of Justice, 'Solving Disputes in the County Courts: creating a simpler, quicker and more proportionate system: A Consultation on reforming civil justice in England \& Wales: The Government Response' (The Stationery Office Limited consultation paper Cm 8274 February 2012) 33

${ }^{119}$ Ibid.

${ }^{120}$ Ibid., 34
} 
scheme as sufficient, there was still the suggestion by some that 'given mediation is so central to this consultation and on-going civil justice reforms, accreditation alone was insufficient and a regulatory framework was required.' ${ }^{121}$ The use of the CMC's accreditation scheme as a form of regulation was considered adequate for some kind of self-regulation but this could be and, is inevitably, a step towards a formal regulatory framework whether applicable only to commercial mediation or one regulatory framework for all types of mediation.

A follow up question as to whether the CMC's accreditation scheme was sufficient was 'what more should be done to regulate civil and commercial mediators?' The fact that the question is 'what more' suggests that there is already regulation of civil and commercial mediators of some kind. This perceived regulation is, no doubt, in the form of the various accreditation schemes, training and codes of conduct that already exist. In any event, it was canvassed that in order to make the CMC's accreditation scheme more efficient, accreditation should be compulsory for all civil and commercial mediators and that 'there was an urgent need for mediation to be put on a more professional footing and for it to be regulated.' ${ }^{122}$ This would ensure compliance and consistency in training throughout the industry. Respondents' views differed as to the form of this regulatory framework. Some suggested that regulation could be in the form of a board, framework or accreditation scheme with the purpose of ensuring consistency of training and quality for mediation so that the existing industry in all its forms is not undermined. However, such regulatory boards, frameworks and schemes can be somewhat bureaucratic in nature and this could impinge upon the flexible nature of the mediation process; regulation should therefore not brandish red-tape. Respondents who believed there should be some sort of regulatory body also pointed out that it should be separate from the CMC in order for transparency and independence to be evident. ${ }^{123}$ Many respondents suggested that 
regulation would encourage continuing professional development, which would raise quality within the industry and ensure that all individuals and organisations involved in commercial mediation kept their knowledge and skills up to date. This, in turn, would promote mediation as a highly trained and quality industry in the eyes of its consumers.

In 2013 the CMC published a consultation in relation to accreditation and regulation. ${ }^{124}$ It is about whether the CMC should be the body providing accreditation. The consultation focused on whether there should be regulation, whether the CMC should be the regulatory body for mediation and whether there should be a 'Mediation Act'. If the CMC were to be the regulator, then the CMC requirements for accreditation would apply to everyone. The Bar Council's response to the consultation accepted that the CMC is understood to be the accredited training provider. And regarding individual mediators, the Bar Council held the position that there was no need for a further level of accreditation. ${ }^{125}$ The Law Centres Network also responded to the consultation that supported the $\mathrm{CMC}$ as being the body to provide a quality standard for mediation training. ${ }^{126}$ This response shows that there is support for a single body to provide the accreditation for mediation - which in itself is a form of regulation - because if every mediator were accredited through one organisation this would ensure a minimum level of standards for the industry.

CEDR has undertaken a number of Mediation Audits to understand mediator experiences and attitudes, the first audit being in 2003, which found that the majority of mediators responding were lawyers (either solicitors or barristers). It found that $76 \%$ of respondents 'believed there should be a single regulatory body for setting and monitoring professional

\footnotetext{
124 The CMC and Accreditation: a Consultation 25 March 2013, http://www.civilmediation.org/downloads.php?f=117 accessed 5 August 2013

125 The Bar Council, 'Bar Council Response to the CMC and Accreditation consultation paper' (Bar Council, May 2013) <http://www.barcouncil.org.uk/media/216132/adrc_final_response_to_cmc_consultation.pdf > accessed 5 January 2016

126 Law Centres Network, 'Response of the Law Centres Network to the Consultation Document 'The Civil Mediation Council and Accreditation' (Law Centres Network May 2013) http://www.lawcentres.org.uk/policy-and-media/papers-and-publications/briefings-andsubmissions accessed 5 January 2016
} 
standards of practice and dealing with complaints'. ${ }^{127}$ In its fifth Mediation Audit in 2012, CEDR found a further $15 \%$ increase in mediation cases and that lawyers were still the dominant profession. ${ }^{128}$ To ensure consistency, and in an attempt to understand changing attitudes in the mediation industry, similar questions to those that had been asked before on standards and regulation were again raised. These were

(a) Would you welcome a single standard of basic professional training of commercial mediators (as against a free market in basic accreditation)?' ${ }^{129}$ and '(b) Do you believe there should be a single regulatory body for setting and monitoring professional standards of practice by commercial mediators and dealing with public complaints against mediators? ${ }^{130}$

The industry continued to be consistent with $52.1 \%$ being in favour of a single standard of basic professional training (question (a) above), and there was increased support with $61.7 \%$ of those in favour of a single regulatory body (question (b) above). Those surveyed appear to be more interested in this issue with the percentage of those who 'do not know' reduced to $9.9 \%$ compared with $18 \%$ of people being unsure in $2010 .{ }^{131}$ The issue is important and it seems it has at last encouraged people to get off the fence and be either for or against a single regulatory body. Unsurprisingly, with the recent CPR amendments, the majority of those in favour of a single regulatory body were lawyer mediators. There is therefore an increase in support for a single basic training standard and support for a single regulatory (over $60 \%$ of people being in favour).

In 2014 CEDR published its Sixth Mediation Audit, ${ }^{132}$ by which time mediation had become viewed as a profession in its own right. The Sixth Mediation Audit sought mediator and lawyer views on the CMC's plans to introduce individual mediator registration schemes and a basic

\footnotetext{
127 Centre for Effective Dispute Resolution, Results of CEDR's first Mediator Audit (CEDR 1 December 2003) <http://www.cedr.com/news/?item=Results-of-CEDR-s-first-Mediation-Audit> accessed 4 June 2013

128 G Massie, The Fifth Mediation Audit: A survey of mediator attitudes and experience (CEDR 12 May 2012) <http://www.cedr.com/docslib/TheMediatorAudit2012.pdf> accessed 3 December 2012, p 3

${ }^{129}$ Ibid., 9

${ }^{130}$ Ibid.

131 Ibid.

${ }^{132}$ CEDR, The Sixth Mediation Audit, 22 May 2014, <http://www.cedr.com/docslib/TheMediatorAudit2014.pdf> accessed 5 January 2016
} 
standard of competence for mediators. The results were that $64 \%$ of mediators were in favour of having a registration scheme and a basic standard of competency. This is significant given the movements (mentioned below) by the CMC to introduce their own form of 'regulation' for mediators. In relation to standards and regulations the Sixth Mediation Audit held that [t]here is still a clear consensus that much more should be done to promote mediation takeup, but most now seem to accept that building a profession is a key element of the campaign, although a few suggest that adopting a more outward-facing focus might assist. ${ }^{133}$

Although regulation is considered a key factor in mediation, what seems to be the focus here is to ensure that more people actually use mediation and that mediation is promoted as an ADR tool.

As there is apparent support for regulating commercial mediation in England and Wales coming from those engaged in the industry, it is necessary to establish the advantages and disadvantages of regulating commercial mediation to understand if in fact, despite the support, regulation is actually required when looking at the issue from the English and Welsh perspective. It can now be argued that a form of 'light touch regulation' has been introduced through the CMC now introducing 'registered mediators' and 'registered mediator providers'. ${ }^{134}$

In order to register with the $\mathrm{CMC}$ as an individual mediator there are certain requirements that the mediator must fulfil. The main requirements are that the mediator must (i) have been trained as a mediator by a CMC recognised training provider; (ii) have current experience as a mediator; (iii) abide by an ethical code of conduct such as the EU Model Code of Conduct for Mediators; (iv) provide their own professional indemnity insurance cover; (v) undertake

\footnotetext{
133 Ibid., 10

134 The Civil Mediation Council, 16 March 2015 <http://www.civilmediation.org/news/cmc-launches-individual-mediator-registration/99> accessed 26 April 2015, 19:55
} 
continuing professional development; and (vi) have their own published complaints handling procedure. $^{135}$

\subsection{Ramifications (both positive and negative) of a regulatory framework}

Clearly there is growing support for the regulation of mediation but what would the advantages and disadvantages of regulating mediation be? Industries are often regulated for a number of reasons, such as to ensure consumer confidence and public trust. This is because a regulatory body acts as a safety net for consumers and provides a facility for disgruntled customers to refer their complaints in relation to the service with which they have been provided. By providing a facility for consumers to complain, it enables them to acquire greater confidence in the industry, which in turn boosts public confidence because they know that if something is wrong with the service their complaint will be dealt with independently by the single regulatory entity. Regulation of mediation could put the industry on a professional footing and encourage mediation to grow in its own right. It would also allow for uniformity in the industry by providing for a single standard of training and accreditation. Furthermore, together with ensuring minimum standards for public confidence, a regulatory body can promote the industry. If there is to be an independent regulatory body then this should be established sooner rather than later to avoid a disconnected body becoming a de facto regulator.

Mediation, however, has been hailed as a flexible and voluntary alternative to litigation and is highly diverse in its nature. The mediation industry consists of lawyer and non-lawyer mediators who add to the process in individual cases through their own knowledge of their industries (such as a mediator on a construction dispute who has worked in that industry and understands how that industry works). As above, mediation is a flexible process and is diverse in nature and it works because of that flexibility and diversity. If there is regulation of mediation

${ }^{135}$ Ibid. 
then this flexibility and diversity might be diminished; and if there is 'over-regulation at this time [it] would be likely to inhibit the development of this emerging dispute resolution mechanism. ${ }^{, 136}$

The mediation industry is reputable and has received judicial support; particularly by some Court of Appeal judges. Mediators are often able to get parties in a dispute to agree to a resolution that the court would not have been able to achieve. This is why the voluntary and flexible nature of mediation is such an important element.

If a single regulatory body should be imposed, it is hoped that the ability of the mediators to create chances for imaginative solutions will not be diminished because this would severely affect the most important function of mediation and one of the reasons why mediation has become a popular form of ADR. The homogenisation of the industry could reduce the very creative results that may occur at mediation, which cannot be achieved through the court system.

The existing accreditation schemes have been around in a structured way ${ }^{137}$ encouraging mediation in all types of disputes and "[t]here is no doubt that this is a process which works and delivers results. ${ }^{138}$ Mediation has expanded and developed into an industry with its own rules for ensuring minimum standards and quality as well as protecting what it is about, i.e. the flexible and voluntary resolution of disputes out of court. Arguably, mediation works - it is not broken and therefore does not need to be fixed by the imposition of a single regulatory body.

\subsection{The enforcement of mediation agreements}

Mediation is a voluntary process, thus, if the parties agree to have their dispute mediated, such contract will not exclude the court's jurisdiction. This is the view consolidated by the case law

\footnotetext{
${ }^{136}$ B Clark and R Mays, 'Regulating ADR - The Scottish Experience' [1996] 5 Webb JCLI, p 5

${ }^{137}$ This is evident from the fact that CEDR has been established since $1990<\mathrm{http}: / /$ www.cedr.com/about us/> accessed 26 April 2015, 20:02 $138 \mathrm{~T}$ Allen and $\mathrm{K}$ Mackir, 'Moves in Mediation: confidentiality, the EU Directive and Regulation', The Barrister Magazine www.barristermagazine.com/archive-articles/issue-43/moves-in-mediation-confidentiality-the-eu-directive-and-regulation.html accessed 29 December 2012
} 
in England and Wales where an agreement to negotiate is in theory, not enforceable. This conclusion was reached in Courtney \& Fairburn v. Tolaini Bros Ltd ${ }^{139}$ when an exchange of letters between the parties, in which the claimant introduced to the defendant someone to finance a construction project, was not seen as an enforceable agreement. Lord Denning understood that a contract to negotiate is not a contract as it is 'too uncertain to have any binding force'. ${ }^{140} \mathrm{He}$ considered that if a contract to negotiate were breached, it would be impossible to assess damages as no one could predict what could have been the result of the negotiation. The idea was that you cannot force someone to negotiate as such conduct is at the parties' discretion. The Courtney ruling was referring to negotiation but in other cases in which the same principle was applied the result was not the same. In Cable \& Wireless Plc v IBM United Kingdom $\mathrm{Ltd}^{141}$ the parties concluded a Global Framework Agreement in which the defendant would supply the claimant information and technology around the globe. Once a dispute was triggered in court, an application for stay of proceedings was made due to the existence of an escalation ADR clause. ${ }^{142}$ The claimant argued that the stay of proceedings in such a case should follow the approach given to the enforcement of arbitration agreements while the defendant argued that the clause was to negotiate and, therefore, it was not enforceable under English and Welsh law. Colman $\mathrm{J}$ referred to the Courtney case and understood that the agreement to 'attempt in good faith to resolve the dispute or claim' in itself could not be

\footnotetext{
${ }^{139}$ [1975] 1 WLR 297

${ }^{140}$ Ibid., p 302

${ }^{141}$ [2002] C.L.C. 1319

${ }^{142}$ The clauses stated: 40. 'Any question or difference which may arise concerning the construction, meaning, effect or operation of this Agreement, any Local Services Agreement or any matter arising out of or in connection with this Agreement or any Local Services Agreement shall in the first instance be referred to the C\&W Project Executive and the IBM Project Executive (both as defined in Schedule 13 (Governance)) for discussion and resolution at or by the next Review Meeting. If the matter is not resolved at such meeting, the matter shall be referred to the next level of C\&W's and IBM's management who must meet within five working days or such other period as the Parties may agree to attempt to resolve the matter. If the matter is not resolved at that meeting, the escalation shall continue with the same maximum time interval through one more level of management. If the unresolved matter is having a serious effect on the Services, the Parties shall use every reasonable endeavour to reduce the elapsed time in completing the process. Neither Party nor any Local Party may initiate any legal action until the process has been completed, unless such Party of Local Party has reasonable cause to do so to avoid damage to its business or to protect or preserve any right of action it may have' 41. 'The Parties shall attempt in good faith to resolve any dispute or claim arising out of or relating to this Agreement or any Local Services Agreement promptly through negotiations between the respective senior executives of the Parties who have authority to settle the same pursuant to Clause 40. If the matter is not resolved through negotiation, the Parties shall attempt in good faith to resolve the dispute or claim through an Alternative Dispute Resolution (ADR) procedure as recommended to the Parties by the Centre for Dispute Resolution. However, an ADR procedure which is being followed shall not prevent any Party or Local Party from issuing proceedings'
} 
enforced. ${ }^{143}$ Nevertheless, as the clause went on to determine that the parties needed to go through an ADR procedure provided by CEDR, Colman $\mathrm{J}$ ruled that specifying the use of CEDR would remove the vagueness mentioned by Lord Denning in Courtney, generating a certainty in the procedure as CEDR has specific rules regarding ADR procedures. For that reason, this was not a mere agreement to negotiate but an agreement to have an alternative method of dispute resolution to solve disputes arising out of the contract that could easily have its compliance verified by courts. ${ }^{144}$

The issue has arisen when an ADR clause would establish a mediation precedent to another form of dispute resolution - most commonly, an arbitration clause. In Holloway \& Anor v. Chancery Mead Limited ${ }^{145}$ proceedings commenced under a contract of sale and purchase of property in which the seller did not comply with its contractual obligations, providing a property with defects that should have been repaired. The contract had an arbitration clause and another clause referring to the National House-Building Council (NHBC) dispute resolution service in which conciliation should take place prior to the arbitration. Once the claimants started the arbitral procedure and the defendant was notified, the latter opposed arbitration arguing that the NHBC dispute resolution system was a condition precedent to arbitration. As a result, the claimants went to court to obtain an order entitling them to refer the dispute to arbitration. The question presented to the judiciary was that the NHBC dispute resolution system, if applicable, 'amounted to an agreement to agree and could not give rise to an enforceable obligation or a condition precedent.' ${ }^{146}$ Ramsey J, based on several precedents, understood that the ADR clause would be enforceable if it met the following requirements:

First, that the process must be sufficiently certain in that there should not be the need for an agreement at any stage before matters can proceed. Secondly, the administrative

\footnotetext{
${ }^{143}$ Cable \& Wireless Plc v IBM United Kingdom Ltd. [2002] C.L.C. 1319, at 1327

$144 \mathrm{~J}$ Colman at 138, referred to mediation as ADR stating that '[a]ccordingly, in the present case I conclude that clause 41.2 includes a sufficiently defined mutual obligation upon the parties both to go through the process of initiating a mediation, selecting a mediator and at least presenting that mediator with its case and its documents and attending upon him. There can be no serious difficulty in determining whether a party has complied with such requirements.'

145 [2007] EWHC 2495 (TCC)

146 Ibid., para. 66
} 
processes for selecting a party to resolve the dispute and to pay that person should also be defined. Thirdly, the process or at least a model of the process should be set out so that the detail of the process is sufficiently certain. ${ }^{147}$

Conversely, in Sulámerica Cia Nacional de Seguros S.A. v. Enesa Engenharia S.A., ${ }^{148}$ the Court of Appeal, confirming the High Court decision, was of the opinion that in a contract establishing mediation precedent to arbitration, such a clause was not enforceable. The case related to two insurance policies for the construction, in Brazil, of one of the world's largest hydroelectric facilities. Arbitration was triggered by the insured party in London due to claims for losses that should be covered by the insurance policy. Once notified, the insurers started an anti-arbitration injunction in Brazil to stop arbitration in England. As a result, the insured went to the High Court seeking an injunction stopping the insurers from pursuing a claim in Brazil. Several arguments were debated in court and one of them was the existence of a mediation clause in the insurance contract determining that before commencing arbitration to solve disputes arising out of the contract, the parties should attempt mediation. ${ }^{149}$ Again, the court had to address the enforceability of such clause. Applying the principles in Cable \& Wireless Plc v IBM United Kingdom Ltd ${ }^{150}$ and Holloway \& Anor v Chancery Mead Ltd, ${ }^{151}$ the Court of Appeal found that the mediation clause was not enforceable as it did not determine a specific mediation process or refer to a specific mediator provider. Lord Justice Moore-Bick, in relation to the mediation clause, declared that

\footnotetext{
${ }^{147}$ Ibid., para. 81

148 [2012] EWCA Civ 638

149 The clause stipulated: 11. Mediation If any dispute or difference of whatsoever nature arises out of or in connection with this Policy including any question regarding its existence, validity or termination, hereafter termed as Dispute, the parties undertake that, prior to a reference to arbitration, they will seek to have the Dispute resolved amicably by mediation. All rights of the parties in respect of the Dispute are and shall remain fully reserved and the entire mediation including all documents produced or to which reference is made, discussion and oral presentation shall be strictly confidential to the parties and shall be conducted on the same basis as without prejudice negotiations, privileged, inadmissible, not subject to disclosure in any other proceedings whatsoever and shall not constitute any waiver of privilege whether between the parties or between either of them and a third party. The mediation may be terminated should any party so wish by written notice to the appointed mediator and to the other party to that effect. Notice to terminate may be served at any time after the first meeting or discussion has taken place in mediation. If the Dispute has not been resolved to the satisfaction of either party within 90 days of service of the notice initiating mediation, or if either party fails or refuses to participate in the mediation, of if either party serves written notice terminating the mediation under this clause, then either party may refer to the Dispute to arbitration. Unless the parties otherwise agree, the fees and expenses of the mediator and all other costs of the mediation shall be borne equally by the parties and each party shall bear their own respective costs incurred in the mediation regardless of the outcome of the mediation.

${ }^{150}$ (n 128)

151 (n 132)
} 
[t]he first paragraph contains merely an undertaking to seek to have the dispute resolved amicably by mediation. No provision is made for the process by which that is to be undertaken and none of the succeeding paragraphs touches on that question. ${ }^{152}$

Hence, the mediation clause was deemed unenforceable.

Nevertheless, in Emirates Trading Agency LLC v Prime Mineral Exports Private Ltd, ${ }^{153}$ a mediation clause that was not precise was considered to be enforceable. The case involved a contract to purchase iron ore in which Emirates Trading failed to lift all of the iron ore as provided for by the agreement. The contract had a dispute resolution clause in which the parties agreed to 'first seek to resolve the dispute or claim by friendly discussion' and if such attempt failed, parties could resort to arbitration. ${ }^{154}$ As a result, arbitration started but without any attempt to negotiate - circumstances that generated a challenge to the tribunal's jurisdiction. The arbitral tribunal recognised its jurisdiction and a challenge was brought to court. Teare $\mathbf{J}$ ruled that the negotiation clause was enforceable but the challenge was not valid as the parties tried to negotiate before starting the arbitral procedure. The interesting part of this case is that although Teare $\mathrm{J}$ thought that the simple clause was not incomplete or uncertain, he actually declared that 'an obligation to seek to resolve a dispute by friendly discussions in good faith has an identifiable standard, namely, fair, honest and genuine discussions aimed at resolving a dispute. $^{155}$

As the case law demonstrates, a test has been established in Holloway to make ADR clauses enforceable. Such framework was followed in Sulámerica; however, in Emirates the same level

\footnotetext{
152 Para. 36

153 (2014) EWHC 2104

154 11. Dispute Resolution and Arbitration

11.1 In case of any dispute or claim arising out of or in connection with or under this LTC including on account of a breaches/defaults mentioned in 9.2, 9.3, Clauses 10.1(d) and/or 10.1(e) above, the Parties shall first seek to resolve the dispute or claim by friendly discussion. Any party may notify the other Party of its desire to enter into consultation to resolve a dispute or claim. If no solution can be arrived at between the Parties for a continuous period of 4 (four) weeks then the non-defaulting party can invoke the arbitration clause and refer the disputes to arbitration. 11.2 All disputes arising out of or in connection with this LTC shall be finally resolved by arbitration in accordance with the Rules of Arbitration of the International Chamber of Commerce ('ICC'). The place of arbitration shall be in London ('UK'). The arbitration shall be conducted in the English language. 11.3 The arbitration shall be referred to a tribunal of three (3) arbitrators, each Party shall appoint one arbitrator and the third shall be appointed by the ICC. Any award of a majority of the arbitrators shall be final and binding upon the parties thereto, and may be entered for enforcement in any court having jurisdiction.

${ }^{155}$ (n 131) para. 67
} 
of scrutiny did not seem to be taken into consideration. Nevertheless, the facts in Emirates do not make the test in Holloway obsolete; on the contrary there was a fulfilment of the prerequisite to mediate before arbitrate. It looks clear that the enforcement of ADR clauses in English and Welsh law have been changing since the decision in Courtney, creating a modern approach to the topic.

If regulation of mediation is to take place in England and Wales, one can argue that its enforcement should have a statutory character. The case law has provided some stability and perhaps, regulating this specific issue might not be a good idea as the current scenario gives security to the parties that wish to mediate. The requirements delineated in Holloway aim at creating certainty, that is, certainty that the parties' intention was to try to mediate the dispute. Courts are perfectly equipped to deal with cases of enforcement of ADR clauses that do not have potential flaws and represent the true intention of the parties to have mediation as a method of resolution of disputes prior to other forms of litigation. Moreover, a statutory provision would eventually be either subjective or it would create a non-exhaustive list of situations in which the mediation clause can be enforced, having a similar result as an examination on a case-by-case basis performed in courts.

\section{Conclusion}

Although several countries have opted to regulate mediation, it does not appear that English and Welsh law will follow this direction, at least for civil and commercial cases. The modernisation of the legal system by giving access to justice through an alternative form of dispute resolution in which parties will reach a settlement is the reason why mediation has been regulated in several jurisdictions. It is a fact that the regulation of mediation, as demonstrated above, can secure the application of this ADR method. However, so far, the framework presented in England and Wales is not unruly; on the contrary, the current scenario is 
sustainable and the industry seems to be satisfied. ${ }^{156}$ Even without a general form of regulation the practice of mediation in England and Wales has thrived ${ }^{157}$. The motivation to regulate identified in other countries can be found in England and Wales such as the examples of family mediation and the mediation option in small claims procedures. Both cases aim at facilitating access to justice reaching the ultimate goal that is an agreement between the parties in a timely and cost effective manner. However, the need to formally regulate the profession of mediators in order to provide more security seems unnecessary to the English and Welsh system. So far, self-regulation is working and it has been accepted by the courts.

Nevertheless, if regulation were to take place it should be in a non-interventionist format, touching peripheral matters as opposed to making a series of bureaucratic procedures to be followed. The mediation market is an established industry and there is public trust in how it works. Too much interference under the idea of security could bring instability and distrust in the use of mediation. For instance, commercial mediation has its own rules, and it provides a service well accepted by the industry. It is flexible, easy to understand, and it allows business people to use their own language in a framework with which they are familiar. And in circumstances where there is a dispute, the parties more often than not want to settle the issues so that they can move on with their business. Thus, establishing a legal procedure for mediation would be counter-productive. As mediation derives of parties' freedom to contract, they should also be free to determine the steps taken through mediation. A mediator is a facilitator who will help parties reach an agreement, if the process becomes too bureaucratic, parties might feel that it is not functional.

Contrary to commercial mediation, family mediation could be an area in which some or more regulation might bring public confidence in the procedure. In family disputes, the parties

\footnotetext{
${ }^{156}$ See above heading 4.1

157 This is particularly so when CEDR has acknowledged a growth of civil and commercial mediation numbers rising from 8,000 in 2012 to 9,5000 in 2014. n. 4 \& 126
} 
are not necessarily well acquainted with the procedures presented to them. Thus, they might feel that the process does not provide the expected guarantee of protection to their rights at a difficult time. Here is an area that perhaps a regulation establishing the necessary requirements to be a mediator could help. When someone engages in family mediation, the person would like to know that the mediator is a qualified person as the mediation will deal with sensitive and personal issues. Regulation could bring such security, however, the law is already providing for a mediation system in family law which is supported by self-regulation. Therefore, civil and commercial mediation is not an area, in England and Wales, which will collapse with a lack of statutory regulation, as the present environment of effective selfregulation, has been well consolidated and is functional and sustainable in its current form. 